University of Minnesota Morris Digital Well

University of Minnesota Morris Digital Well

Spring 2014

\title{
"Quizá volverán ...": Four Incidents of Rape (or Threatened Rape) in Don Quijote de la Mancha
}

Stacey L. Parker Aronson

University of Minnesota - Morris

Follow this and additional works at: https://digitalcommons.morris.umn.edu/span_facpubs

Part of the Spanish Literature Commons

\section{Recommended Citation}

Aronson, S. L. P. "'Quizá volverán ...": Four Incidents of Rape (or Threatened Rape) in Don Quijote de la Mancha." Cervantes: Bulletin of the Cervantes Society of America, vol. 34 no. 1, 2014, pp. 121-140.

This Article is brought to you for free and open access by the Faculty and Staff Scholarship at University of Minnesota Morris Digital Well. It has been accepted for inclusion in Spanish Publications by an authorized administrator of University of Minnesota Morris Digital Well. For more information, please contact skulann@morris.umn.edu. 


\section{"Quizá volverán ...": Four Incidents of Rape (or Threatened Rape) in Don Quijote de la Mancha}

Stacey L. Parker Aronson

I n Miguel de Cervantes's novel Don Quijote de la Mancha, the reader meets Marcela, the iconic shepherdess and proto-feminist who defends her right to love and to give herself to whom she chooses, not necessarily to whomever chooses her. "Si yo conservo mi limpieza con la compañía de los árboles, ¿por qué ha de querer que la pierda el que quiere que la tenga con los hombres? [...] [T]engo libre condición, y no gusto de sujetarme" (I.I4:I69). While Marcela affirms "su derecho a vivir fuera de los confines de la construcción del mundo creado por las leyes del patriarcado" (Zavala 323), other Cervantine women find themselves in the precarious situation of having to defend against sexual assault. In the entirety of Don Quijote, there are four pivotal episodes in which women are either threatened with rape or are actually forcibly raped. These episodes involve the following characters: Dorotea (two episodes); the woman who pleads her case to Sancho while he governs his ínsula; and the young village women described by Sancho's wife Teresa in her letter to him. In three of these four episodes, women are able to resist being raped, and in one episode, they are not.

It appears that, at least on some level, whether intentionally or unintentionally, the narrative voice of Don Quijote creates a rhetorical environment in which social disparity contributes to rape or the threat

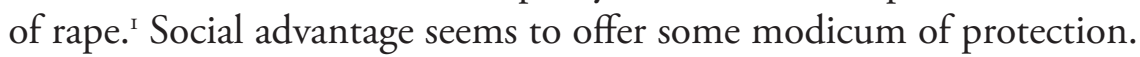

I My use of the term "social" is intended to encompass both socio-economic and sociopolitical dimensions and to insinuate a difference in status based on power. 
In addition, a woman's consent or the appearance of consent might have been an intentional strategy to avoid greater harm. The logical physical superiority of males does not ensure their success at raping the females. What appears to hold true is that the greater the social disadvantage of the female victim in relation to her perpetrator, the greater the likelihood that she will be raped when threatened. In addition, the greater the social advantage of the female victim in relation to her perpetrator, the greater the likelihood that she will successfully defend herself against rape. As Renato Barahona details in his study Sex Crimes, Honour, and the Law in Early Modern Spain, the crime of rape and related sexual misconduct could be defined in myriad ways ranging from forced sexual intercourse to a reneged promise of marriage. ${ }^{2}$ In addition, a woman's resulting loss of honor could be resolved in a number of ways, the most common being financial remuneration and, strangely enough, the obligation of the perpetrator to marry the aggrieved female party. Most crimes of sexual misconduct, which Barahona terms estupro, involved similar elements:

I) courtship, persuasions, and offers; 2) seduction and premarital sexual relations-relations, it should be underscored, generally carried out under the promise and assurance of matrimony; 3) a breach of promise to marry by the defendant (sometimes accompanied by his flight — in effect, by abandonment of the female); 4) assertions of shame and dishonor to the plaintiff in the aftermath of the deception and desertion; and 5) claims of damages. (6)

Criminal charges were usually filed because of specific actions carried out on the part of the male, including his refusal to marry the aggrieved female; his desertion of the female to avoid marriage or his subsequent marriage to another; or his refusal to provide financial support to compensate for the loss of the woman's virginity or to support a child born of the relationship (Barahona 27-28). For the Vizcayan

2 On sex crimes in medieval Spain, and the practice of marriage to one's rapist as a way to mitigate the damage to a woman's honor, see Córdoba de la Llave (El instinto diabólico 78-80). On punishments administered in the case of rape, see Narbona Vizcaíno (I45-48). 
women in Barahona's study who elected to seek justice, they had the option to seek a financial resolution either out of court (also an option in other locations within Spain) or in court (I2I).

Many of these legal resolutions depended a great deal upon the social status of the parties involved, both victim and victimizer. Naturally, crimes committed up the social ladder necessitated more severe punishments, while those committed down the social ladder did not and might not even be considered crimes at all. For example, Joan Ramon Resina documents the case of a nobleman who promised to marry a countrywoman in order to obtain her consent to sexual intercourse with him. When she pled her case to the court to obligate him to fulfill his promise to marry her, the court ruled against the woman, claiming that she should have known better that a nobleman would never follow through on his promise to marry her (Resina 550-5I). ${ }^{3}$ In another case, documented in detail by Barahona, Mari Sanz de Millica (I634-36) charged Diego de Irusta, a wealthy local politician, with the crime of defloration. Although her lawsuit was ultimately settled (for much less than she had originally requested), she was told that she, too, should have known better and "that it was absurd for persons of their status to seek promise of matrimony from a man of Irusta's condition ('que hera disparate pretender palabra de matrimonio jente de su calidad con la de don Diego')" (Barahona 89). Also, according to the priest Martín de Azpilcueta Navarro, if a man who seduced a woman pertained to a higher social class than she, she was blamed for having "pretended to be deceived" (Manual II7; Perry 59).

At times the legal interpretation of rape varied depending upon where it was applied and to what specific act it referred. ${ }^{4}$ Although Renato Barahona refers to cases of sexual misconduct generally as estupro, Abigail Dyer explains in her article "Seduction by Promise of

3 This misogynistic idea emphasizing the woman's responsibility in her own dishonor can be found in Martín de Azpilcueta’s (I49I-I586) Manual de confesores y penitentes (cited in Castro, [100]) and in Manuel Rodríguez's Suma de casos de conciencia (1595) (qtd. in Rico [25I]).

4 In The Secret History of Gender, Steve J. Stern observes that in colonial Mexico "Spanish law technically distinguished between rape as estupro, the deflowering of an 'honest' virgin, and rape as violación, a more inclusive category that included among its subsets sexual assault on non-virginal women and seductions accompanied by false promises of marriage" (409). 
Marriage: Law, Sex, and Culture in Seventeenth-Century Spain" that the legal term estupro was problematic and "meant both seduction and rape, though jurists and deponents usually distinguished between the two by calling one estupro 'by promise of marriage,' (estupro bajo palabra de matrimonio) and the other 'forced' estupro (estupro forzoso)" (444). As Dyer notes, the official resolutions for the violation of a sexual honor code (such as the death of the participants) frequently gave way to legal ones often initiated by parents on behalf of daughters as they sued for "seduction by promise of marriage." Attempts at a legal remedy-generally marriage or money-were most often sought out when a lover announced his intention to marry someone else or as a way to guarantee child support when the woman became pregnant. According to Dyer,

Using the language of honor, seventeenth-century litigants and the law courts that heard these cases regularly transformed women's "dishonorable" pre-marital sexual behavior into seduction by promise of marriage, a crime in which the woman was a blameless victim. Seizing the opportunity provided them by law, jurists and litigants used seduction litigation as a way to eliminate the need for blood revenge. Plaintiffs, in particular, used seduction litigation as a means to shift culpability for sexual transgression away from themselves and onto their seducers, thereby absolving themselves both of sexual sin and dishonor. (44I)

Transgressive acts, such as admitted female sexual desire-Dorotea's for Fernando-could be re-categorized through the justice system to seduction litigation by promise of marriage, a crime in which women assumed no blame and maintained their honor.

\section{DOROTEA I}

The episodes involving Dorotea are some of the most studied of Don Quijote. In part one, chapter twenty-eight, Dorotea finds herself in what she perceives to be an inextricable situation. She has found her- 
self alone with Fernando, a dishonorable cad who desires to have sexual relations with her and had previously confessed that desire to another male friend, Cardenio. While she admits to being quite taken by his amorous advances ("y no me pesaba ver en sus papeles mis alabanzas [que en esto, por feas que seamos las mujeres, me parece a mí que siempre nos da gusto el oír que nos llaman hermosas]” [I.28:354]), Dorotea fears that her rejection of Fernando might provoke him to physical violence and to rape. In addition, because he is alone with her in her room, she fears that she will be unable to provide convincing evidence to corroborate her innocence to her parents in the event that he does rape her. In response to her reluctance, he promises to marry her: "con palabras eficasísimas y juramentos estraordinarios me dio la palabra de ser mi marido" (I.28:357). She weighs her options, aware that she and Fernando pertain to different social classes, a situation that does not typically lead to marriage. She admits an overpowering sexual attraction to him and suggests that even if she had tried to resist his sexual advances, either she would have been powerless to do so or he would not have permitted her to do so: "me le hallé delante, cuya vista me turbó de manera que me quitó la de mis ojos y me enmudeció la lengua; y, así, no fui poderosa de dar voces, ni aun él creo que me las dejara dar, porque luego se llegó a mí, y tomándome entre sus brazos (porque yo, como digo, no tuve fuerzas para defenderme, según estaba turbada)" (I.28:355). Allowing herself to believe the purported sincerity of his professions of love, Dorotea consents to sexual relations with Fernando and utilizes a complex argument to justify her actions:

5 There are at least two other characters—Leandra (I.5I) and Claudia Jerónima (2.60)who are promised marriage and then abandoned by unscrupulous men. In Leandra's case, she runs away with Vicente de la Roca, intending to marry him. He robs her and abandons her in a cave "sin quitalle su honor" (I.51:635), but does not rape her. In Claudia Jerónima's case, Vicente Torrellas promises to marry her but reneges on his promise and marries another woman. They never consummate their purported engagement: "Finalmente, él me prometió de ser mi esposo y yo le di la palabra de ser suya, sin que en obras pasásemos adelante" (2.60:I224). I have chosen not to include these characters in this study because, in both cases, the women are not raped nor does sexual intercourse occur, details which would have allowed them to bring charges of either rape ("estupro forzoso") or abandonment ("estupro bajo promesa de matrimonio") according to Dyer. 
Sí, que no seré yo la primera que por vía de matrimonio haya subido de humilde a grande estado, ni será don Fernando el primero a quien hermosura, o ciega afición, que es lo más cierto, haya hecho tomar compañía desigual a su grandeza. Pues si no hago ni mundo ni uso nuevo, bien es acudir a esta honra que la suerte me ofrece, puesto que en éste no dure más la voluntad que me muestra de cuanto dure el cumplimiento de su deseo; que, en fin, para con Dios seré su esposa. Y si quiero con desdenes despedille, en término le veo que, no usando el que debe, usará el de la fuerza, y vendré a quedar deshonrada y sin disculpa de la culpa que me podrá dar el que no supiere cuán sin ella he venido a este punto: porque ¿qué razones serán bastantes para persuadir a mis padres, y a otros, que este caballero entró en mi aposento sin consentimiento mío? (I.28:358; my emphasis)

According to Francisco Márquez Villanueva, Dorotea, as an only child, has assumed the responsibility for much of the administration of their farm, and her intelligence has enriched the family coffers and social position (27). In fact, he suggests that what she lacks in social class, she makes up for in authority, likely enjoying more within the family than Fernando himself does. Dorotea's family is part of a prosperous land-owning middle class and not the humble peasant class she seems to imply when she considers giving herself to the aristocratic Fernando (26): "Sí, que no seré yo la primera que por vía de matrimonio haya subido de humilde a grande estado, ni será don Fernando el primero a quien hermosura, o ciega aficción, que es lo más cierto, haya hecho tomar compañia desigual a su grandeza" (I.28:358; my emphasis). Some readers might be tempted to view Dorotea as an opportunist, one who struggles to make the best out of a bad situation by marrying Fernando and, therefore, to increase her social status. Given that the threat of rape may or may not be imaginary, Dorotea avoids being raped or convinces herself that she avoids being raped by consenting to sexual relations with Fernando. Some literary critics have speculated that she is, in reality, demonstrating her own sexual desires by having sexual relations with Fernando, including Márquez Villenueva who writes that 
"Dorotea es demasiado lista para dejarse seducir y demasiado enérgica para dejarse forzar," suggesting that women can somehow avoid rape by sheer force of will or by being excessively energetic (28; my emphasis). Perhaps she justifies her own actions by suggesting that they are actually motivated by fear, the fear of being raped. Based upon what she says, she claims to defend herself and her honor by relinquishing her body on the altar of what she reasons is marriage. ${ }^{6}$ When she delivers her stirring oratory in the inn to persuade Fernando to relinquish his hold on Luscinda and to marry her, she utilizes a simple rhetorical strategy: she tells him repeatedly that he is hers- "no será posible que tú dejes de ser mío" (I.36:468) and "porque eres mío" (I.36:468)—and that she is his- "yo soy tu esposa" (I.36:469). She continues to emphasize their social inequality as a way to stroke his ego and ultimately to get what she wants, which is to marry him: "Y si no me quieres por la que soy, que soy tu verdadera y legítima esposa quiéreme, a lo menos y admíteme por tu esclava” (I.36:469).

Despite being a country with a theoretically strict sexual honor code, Spain actually demonstrated a more fluid attitude with regard to sexual matters. Dyer cites statistics involving pre-marital cohabitation and pregnancy and references others who have come to the same conclusion. In her article "Ellusive Virtue: Rethinking the Role of Female Chastity in Early Modern Spain,” Allyson M. Poska provides convincing historical evidence to prove that, despite the appearance of a societal obsession with female chastity and its attendant preoccupation with honor, pre-marital and extra-marital sexual activity was common in Spain among many regions and among many social strata. She argues that "The restrictive discourse on female sexuality and honor favored by Spanish elites and enthusiastically investigated by early modern historians had little resonance among the majority of the Spanish population" (I36) and that "female chastity and honor [were]

6 Literary critics are divided as to her true motivations (Márquez Villanueva 29). For example, Ramón Nieto characterizes Dorotea as "una mujer ambiciosa y fantasiosa, con la cabeza llena de pájaros de grandeza" and at the same time very inclined "a llegar a donde haga falta para conseguir su objetivo" (499). Sander Gilman concurs, saying that she "expresa sin recelo ninguno su afán de casarse con alguien de superior categoría social y decide fríamente dejarse seducir con ese fin" (I7). 
not central to the formulation of sexual mores among most Spaniards" (I46).7 In another study titled "An Ocean Apart: Reframing Gender in the Spanish Empire," Poska also notes that this same attitude regarding the lack of correspondence between female sexual activity and honor was also evident in the colonies, thereby suggesting the variability of the concept of female honor: "While aristocratic women were expected to remain chaste (although they regularly did not), lower-class women could maintain their honor through hard work, honesty, and self-reliance, their chastity notwithstanding" (40).

\section{DOROTEA 2}

Later, Fernando abandons Dorotea to marry another more socially appropriate female partner, Luscinda. Abandonment after a relationship had been sexually consummated could also be legal grounds for a charge of rape: "seduction by promise of marriage" (Dyer 444). Abandonment was considered such a serious offense to the social order that Baharona comments that, "The disgrace and damage to [a woman's] good name, however, were due more to the aborted marriage plans than to the loss of chastity and charges of promiscuity" (53). In another article, titled "When Love Goes Wrong: Getting Out of Marriage in SeventeenthCentury Spain," Poska details the Cartas de Apartamento, legal documents "agreed to by both parties, [that] terminated the lawsuits over broken marriage promises, thus successfully breaking an engagement or bringing compensation to a woman seduced and left with a child" (874). Dorotea does not resort to legal measures. Instead, she disguises herself as a young man, transforming herself from "virgin to virago"

7 Poska's Women \& Authority in Early Modern Spain demonstrates that "through amancebamiento all women could engage in sexual relationships and produce the children that were critical to the maintenance of the family line in a region where women's marital prospects were limited by male migration [...]. Galician families did not attach any stigma to illegitimate birth" (7I). In "An Ocean Apart" she also notes that "Women in central and southern Spain were more likely to conform to the constrained sexual expectations of the honor code than their counterparts in the north [Galicia], where illegitimacy rates were high, women married late, if at all, and inheritance patterns often favored women" (40). On the practice of extramarital cohabitation in Medieval Spain, see Córdoba de la Llave ("A una mesa y una cama"). On the practice of extra-marital sexual relations, see Testón Nuñez (I43-I9I). 
and takes refuge in the wilderness, her only company being her male servant (Welles I6).

The episode of relevance to this study is the attempted rape of Dorotea by her male servant. At an opportune moment, this previously faithful servant takes advantage of Dorotea's vulnerability and isolation, more than her admitted beauty, by trying to entice her to consent to a sexual encounter. The narrative voice does not allow for the possibility of an alternate interpretation to his actions, as it did with Fernando, and Dorotea does not merely suspect that her male servant might try to rape her. When she refuses to acquiesce to his sexual advances and repudiates him, her male servant does, in fact, try to rape her by force:

Pero como suele decirse que un mal llama a otro y que el fin de una desgracia suele ser principio de otra mayor, así me sucedió a mí, porque mi buen criado, hasta entonces fiel y seguro, así como me vio en esta soledad, incitado de su mesma bellaquería antes que de mi hermosura, quiso aprovecharse de la ocasión que a su parecer estos yermos le ofrecían, y, con poca vergüenza y menos temor de Dios ni respeto mío, me requirió de amores; y, viendo que yo con feas y justas palabras respondía a las desvergüenzas de sus propósitos, dejó aparte los ruegos, de quien primero pensó aprovecharse, y comenzó a usar de la fuerza. Pero el justo cielo, que pocas o ningunas veces deja de mirar y favorecer a las justas intenciones, favoreció las mias, de manera que con mis pocas fuerzas y con poco trabajo di con él por un derrumbadero, donde le dejé, ni sé si muerto o si vivo[.] (I.28:362-63; my emphasis)

The likely physical superiority of the servant, despite his lower social position, and Dorotea's insistence on her physical inferiority — "con mis pocas fuerzas" (I.28:363)—belie the minimal effort required by her"con poco trabajo" (I.28:363) — to overcome her attacker. Dorotea's strategically advantageous position on the precipice endows her with temporary physical advantage. Yet she attributes her success to divine intervention: "Pero el justo cielo, que pocas o ningunas veces deja de mirar y favorecer a las justas intenciones" (I.28:363). This fact, together 
with her coincidental social superiority, allows her to defend herself against the intended rape and likely to kill her attacker by pushing him over a precipice. His fall and likely death mirror his position as Dorotea’s social inferior.

\section{Woman to Sancho}

In part two, chapter forty-five, an alleged rape victim's innocence is questioned in the only other incident involving an accusation of rape in Cervantes's novel. When Sancho is installed as governor, a woman appears before him, charging that a man had raped her:

- Justicia, señor gobernador, justicia, y si no la hallo en la tierra, la iré a buscar al cielo? Señor gobernador de mi anima, este mal hombre me ha cogido en la mitad dese campo y se ha aprovechado de mi cuerpo como si fuera trapo mal lavado, y, ¡desdichada de mí!, me ha llevado lo que yo tenía guardado más de veinte y tres años ha, defendiéndolo de moros y cristianos, de naturales y estranjeros, y yo siempre dura como un alcornoque, conservándome entera como la salamanquesa en el fuego o como la lana entre las zarzas, para que este buen hombre llegase ahora con sus manos limpias a manosearme. (2.45:1087-88)

The man, described as a pig herder, claims that she is a prostitute and, therefore, the sex was consensual_- "Dice que la forcé, y miente, para el juramento que hago o pienso hacer; y ésta es toda la verdad, sin faltar meaja" (2.45:I088) — and that she only alleged rape after he was unable to pay her the amount she required. It is a classic case of "He said, she said." The reader is encouraged to side with Sancho's assessment of the situation and of the woman's claim that she was raped. Sancho doubts the sincerity of the woman's accusation and devises a plan to determine the truth. He gives her a pouch filled with money and orders the alleged rapist to try to take it from her. When the man is unable to do so due to the woman's superior physical prowess ("yo me doy por rendido 
y sin fuerzas, y confieso que las mías no son bastantes para quitársela” [2.45:1089]), Sancho renders his judgment:

Hermana mía, si el mismo aliento y valor que habéis mostrado para defender esta bolsa le mostrárades, y aun la mitad menos, para defender vuestro cuerpo, las fuerzas de Hércules no os hicieran fuerza. Andad con Dios, y mucho de en hora mala, y no paréis en toda esta ínsula ni en seis leguas a la redonda, so pena de docientos azotes. ¡Andad luego, digo, churrillera, desvergonzada y embaidora! (2.45:I090; my emphasis)

In the episode between the woman and the pig herder in Sancho's ínsula, the two individuals who plead their respective cases to Sancho are both villagers and, therefore, pertain to similar socially lower levels. Because the woman is at least equally as strong as the man in defending her purse, Sancho determines that in this case, although sex might have occurred, it did not constitute rape as it was not carried out against her will. ${ }^{8}$ Laughter inevitably ensues as the audience and the readers are obligated to side with Sancho's assessment of the case, and the woman's character is not represented in such a way as to elicit sympathy. Because of her obvious physical strength, she is not represented as a fragile female in desperate need of male salvation.

This scene is significant because of the fact that the woman and the pig herder have access to a type of legal due process as represented by Sancho because they have the right to bring their case to him for his judgment. There appears to be a correlation between their access to legal resolutions and their equivalent social status. Even though Sancho does not rule in the woman's favor, his innocent belief in the impartiality of justice suggests an open-minded, fair process, and he represents a one-man jury of their peers, so to speak.

8 Falcón provides interesting commentary on a once all too common judicial tendency to blame the victim for her own rape by suggesting that a lack of physical injury was evidence that she had not fought back and perhaps had consented to the sexual relations (95-97). This is the same argument utilized by Sancho. 


\section{TERESA}

Sancho's beloved wife Teresa narrates the only episode in the entire work in which the readers are led to believe that multiple acts of forcible rape, although not witnessed, do indeed take place. While her husband Sancho is away governing his island, Teresa dictates a letter to him, transcribed by a young monk, in which she recounts the hardships that she and other women in her village face on a routine basis, one of which is the threat of rape.

Hogaño no hay aceitunas, ni se halla una gota de vinagre en todo este pueblo. Por aqui pasó una compañía de soldados: lleváronse de camino tres mozas deste pueblo; no te quiero decir quién son: quizá volverán y no faltará quien las tome por mujeres, con sus tachas buenas $o$ malas. (2.52:1157; my emphasis)

Teresa does not sentimentalize the kidnapping and sexual violence to which these village girls will inevitably fall victim. Instead, her matterof-fact, minimalistic description suggests that rape is a daily occurrence, its seriousness being on a par with the lack of food supplies. In her study of women in Don Quijote, Lidia Falcón argues that Teresa provides an interesting foil to her husband Sancho. While her practicality is grounded in a concrete reality, she lacks the critical acumen to question this reality. Although it may be true that, according to Falcón's assessment, Teresa's words reflect "la opresión social, la explotación económica, la división de clases, la resignación cristiana ante tal estado de cosas y el miedo ancestral del pueblo a luchar por transformer el mundo en un lugar más justo, bien contradictorio al ideal quijotesco" (69), she is the only character in Don Quijote whose words, rooted in socio-historical reality, recount the abduction and rape of powerless village girls confronted by marauding soldiers. I. A. A. Thompson details this all too ubiquitous threat that jeopardized the safety of all citizens, including women: 
The annual movement of forty or more companies [of soldiers] across Castile left in its wake a trail of destruction and rapine. An endless series of robberies, murders, rapes, malicious and wanton violence, jailbreaks, even pitched battles between soldiers and civilians repeated year after year stretched along all the most traversed routes of the kingdom. The coming of a company of soldiers was awaited with the same trepidation as a hurricane. Those who could fled its path; those who could not were forced to abandon their trades to stay at home to protect their wives, their daughters, and their property. (II3; my emphasis)

In the extra-textual context of seventeenth-century Spanish society, conventional wisdom has long held that these dishonored village girls would have had few options, a plethora of socially appropriate marriage prospects likely not being one of them. Poska asserts that "the restrictive discourse on female sexuality and honor favored by Spanish elites and enthusiastically investigated by early modern historians had little resonance among the majority of the Spanish population" and that "female chastity and honor [were] not central to the formulation of sexual mores among most Spaniards" ("Ellusive Virtue" I36, I46). For Poska, a woman's virginity and sexual purity would have had little actual impact on her future marital prospects. In an unusual twist for an early modern writer, Cervantes presents a literary reality in which a character-Teresa-acknowledges that the act of rape does not diminish the worth of the village girls as potential future marriage partners. Perhaps this is indicative of a demonstrable female solidarity between the young women and Teresa, who knows them and who has a young daughter of her own who could just as easily have fallen victim, given her own vulnerability due to her father's absence. In any event, it is the revelation of a social reality: soldiers could behave with impunity towards lower-class citizens, and less powerful victims lacked access to the legal system that might offer them some justice and naturally feared armed retaliation. In fact, to protect the village girls from further shame, Teresa chooses to not reveal their identities, not even to her 
husband, nor does she question their complicity.9 As Teresa dictates, "quizá volverán y no faltará quien las tome por mujeres, con sus tachas buenas o malas" (2.52:II57; my emphasis). The logical power imbalance due to the fact that the rapists are soldiers and their victims are obviously vulnerable village girls, together with Teresa's matter of fact narration, preserve the village girls' innocence, at least from Teresa's point of view.

\section{Female Voices}

All of these narratives about rape are communicated via female voices. Dorotea recounts her own stories and, thereby, controls her own discourse to a sympathetic audience composed of men and women. The woman who pleads her case to Sancho also controls her own discourse, but her discourse is mediated by males (the pig herder and Sancho), both of whom accuse her of lying and whose opinions carry the day. The narrative Teresa intends to communicate to Sancho is compelling because of the multiplicity and complexity of its narrative filters. Due to their lengthy separation, Teresa must rely on this type of communication, albeit infrequent, with her husband Sancho to keep him apprised of activities within the family and within the village.

While Teresa-a female voice-is the primary framer of this narrative, she does not have the proverbial last word as there are at least two other interlocutors between her and Sancho who contribute to that way in which she is able to communicate the narrative that she intends for him to receive. The voices of both these interlocutors are male. The village girls also do not have the opportunity to tell their own stories in their own words. While Teresa technically pertains to a culture that recognizes the primacy of written communication, Teresa is a vestige of an oral culture that depends upon multiple interlocutors to transcribe her thoughts and voice them aloud. The story Teresa narrates was dictated to and written by someone else (a young monk); ${ }^{\text {io }}$

9 Perhaps, because Teresa is narrating this incident to a scribe in the form of a letter, she is reluctant to reveal the names of the young women. She may also be sensitive to the fact that someone else will read the letter to Sancho.

Io In Oral and Literate Culture in England I500-I700, Adam Fox writes of how an illiterate person might avail himself of the writing skills of "a clergyman or a tradesman, an apprentice 
and the story Sancho is intended to read (or hear) is intercepted and read aloud by someone else (Don Quijote). In reality, it is unknown whether or not Sancho ever actually reads or hears the letter intended for him. Once Don Quijote reads the letter aloud in the presence of the Duke and Duchess and those in attendance it is not referred to again. The analogous acts of writing and reading presuppose a social level to which neither Sancho nor Teresa pertains as well as a degree of control they do not have. These individuals - the young monk and Don Quijote-inhabit a more privileged social level than either Teresa or Sancho because they are literate and have enjoyed the benefits of some degree of education. ${ }^{\text {II }}$ Teresa's narration may only seem matter of fact and minimalistic to the extra-textual reader because either Teresa is illiterate or she lacks the more sophisticated vocabulary and register that would allow her to express the depth of emotion that such a situation might provoke and certainly merits. Also, because Teresa's letter is intended to be received by her husband (and perhaps simultaneously by someone who then reads it to him) and not shared publically, she forgoes the decorum required of a more formal address, and some of her topics provoke laughter from those further up the social scale. ${ }^{12}$ Teresa is well aware of the narrative control exercised by the transcriber and she chooses hers carefully so as to avoid ridicule.

El bachiller se ofreció de escribir las cartas a Teresa, de la respuesta, pero ella no quiso que el bachiller se metiese en sus cosas, que le tenía por algo burlón, y, así dio un bollo y dos huevos a un monacillo que sabía escribir, el cual le escribió dos cartas, una para su marido y otra para la duquesa, notadas de su mismo caletre, que no son las peores que en esta grande historia se ponen, como se verá adelante. (2.50:II4O; my emphasis)

or a schoolboy" or even a barber whose "shops acted both as centres of news and gossip and as places where newsletters or pamphlets might be seen" (39).

II On illiteracy in Spain, see Frenk; and Rodríguez and Bennassar.

I2 "Las cartas fueron solenizadas, reídas, estimadas y admiradas" (2.53:II 8 ; my emphasis) 
Another way to compare these four episodes of threatened and actual rape is to consider the related legal concepts of honor and reputation. According to Dyer,

Spanish law centered on two separate but intertwined legal concepts: honor and reputation. In secular and ecclesiastical courts, honor was commonly understood as being dependent upon extrinsic factors (for example, injury caused by another person). Reputation was understood as intrinsic, a quality inherent in an individual's character. Dishonor, [...] was brought about through circumstances external to the dishonored party, such as an insult or a bodily attack. Ill repute, on the other hand, derived from the circumstances of a person's birth or from law. (447-448; my emphasis)

Dyer's study, although focusing on rural Galicia, is useful for our purposes, even though her research upholds the idea that the concept of honor varied throughout Spain. Her understanding of these legal terms, however, seems to correlate to the success or failure of a woman's attempt to achieve a legal resolution. Surprisingly, the courts afforded young unmarried women who had engaged in sexual misconduct a legal remedy by recasting them as victims:

By bifurcating the concepts of female sexual honor and a woman's reputation, secular courts provided young unmarried women with a safety net against social ruin, in the form of victim status. Spanish law shifted responsibility for premarital sexual misconduct onto the male partner, leaving any woman in possession of a good reputation before the seduction had occurred, or any woman who could fabricate a good reputation with the help of her lawyer and her witnesses, able to claim continued respectability by virtue of her victimhood. (45I)

In the two episodes involving Dorotea, Dorotea does not choose to seek out justice in the courts for Fernando's crime of "seduction by promise of marriage" (Dyer 444). She does seek out her own type of 
judicial resolution in the court of public opinion at the inn, after her lover, having announced his intention to marry Luscinda, appears with her, obligating Dorotea to plead her case to Fernando and the other witnesses gathered there and to allege an affront to her honor (although not to her reputation). She alleges a similar affront to her honor (although, again, not to her reputation) when her male servant tries to rape her, although she seeks no public redress for this attack because she has enacted a blood revenge. She is represented as a victim.

When the alleged rape victim seeks out her own justice before Sancho, likely some type of financial compensation or punishment for the alleged perpetrator, Sancho calls into question her reputation and threatens to punish her for what he perceives to be her false accusations and her sexual licentiousness. Evidenced by the fact that she appears with her skirt raised_- "ella la saya levantada" (2.45:1089)—in an immodest manner in her struggle to protect her bag of money from the pig herder, she is not represented as a victim, and Sancho punishes her with exile and the threat of a flogging if she violates his order (2.45:1090).

In the episode involving the abduction of the village girls by soldiers, Teresa does not disparage their reputations. They have suffered an affront to their honor by their having been raped, but their good reputations will allow them to find suitable marital partners if and when they return to the village. They are represented as victims.

What seems to render Cervantine women vulnerable to sexual assault is their social status in relation to that of their attackers. Whereas elevated social status may not make women less vulnerable to rape in an extra-textual context, it does provide women an advantageous position from which they may appreciate and enjoy greater levels of security. The textual phenomenon of social status, at least as presented in Don Quijote, renders the Cervantine women more or less likely to overcome sexual assault. Rape is attempted or threatened on at least four occasions and is overcome only when the victim and attacker pertain to similar social strata or when the potential victim pertains to a higher social strata than her attacker. Of the four, only two represent actual forcible sexual assaults. In one involving Dorotea and her male servant, 
the victim is able to physically overcome her socially inferior attacker. In the other involving village girls carried off by soldiers, the victims are not; the insinuation is that they will be raped by men in superior numbers with superior strength who behave with wanton disregard for the women's physical safety.

These rape victims are not left entirely without resources. Despite the fact that only one woman seeks legal redress for her loss of honor (i.e., the woman who unsuccessfully pleads her case to Sancho), it was a common method by which to seek justice in various forms, sometimes financial compensation and sometimes marriage, as evident in Barahona's study. Coincidentally, she is the only woman not represented as a victim, due to her sullied reputation. In the cases of the other women, specifically of Dorotea and the village girls, they are represented as victims due to their loss of honor. Dorotea acts in good faith, confident that Fernando will eventually be persuaded to keep his word and marry her.

The only women who are actually forcibly raped in Don Quijotethe village girls - are anonymous, and they never actually appear as characters in the narrative in their own right and do not have the opportunity to tell their own stories in their own voices. By the time the readers hear their tragic story, as recounted by Teresa, it is too late to save them. Despite Teresa's hopeful assertion that they may one day return to the village ("Quizá volverán" [2.52:1157]), the village girls exit the narrative never to be seen or heard from again. They are the most socially disadvantaged victims in relation to their perpetrators and the only characters who are actually forcibly raped. They remain silent, their own voices rendered authorially and narratively silenced, as is true in the case of the vast majority of rape victims. It is only through Teresa's epistolary recounting of the traumatic event that the readers are able to bear witness. ${ }^{13}$

aronsosp@morris.umn.edu University Of Minnesota, Morris

I3 I gratefully acknowledge the generous assistance and encouragement I received from Becca Gerken for reading and commenting on an earlier draft of this article. 


\section{Works Cited}

Azpilcueta Navarro, Martín de. Manual de confesores, y penitentes, que clara y brevemente contiene la universal, y particular decisión de quasi todas las dudas, que en las confesiones suelen ocurrir de los pecados absoluciones, restituciones, censuras, irregularidades. Toledo: Juan Ferrer, I554.

Barahona, Renato. Sex Crimes, Honour, and the Law in Early Modern Spain: Vizcaya, IS28-I735. Toronto: U of Toronto P, 2003.

Castro, Américo. "El Don Juan de Tirso y el de Moliere como personajes barrocos." Hommage a Ernest Martinenche. Paris: Editions d'Artrey, 1939. 93-III.

Cervantes Saavedra, Miguel de. Don Quijote de la Mancha. Ed. Francisco Rico. Galaxia Gutenberg, 2005.

Córdoba de la Llave, Ricardo. "A una mesa y una cama: Barraganía y amancebamiento a fines de la edad media." Saber y vivir: Mujeres, antigüedad y medievo. Eds. María Isabel Calero Secall and Rosa Francia Somalo. Málaga: Universidad de Málaga, 1996. I29-I53.

-. El instinto diabólico: Agresiones sexuales en la Castilla medieval. Córdoba: Universidad de Córdoba, 1994.

Dyer, Abigail. "Seduction by Promise of Marriage: Law, Sex, \& Culture in 17thCentury Spain." Sixteenth Century Journal 34.2 (2003) 439-55.

Falcón, Lidia. Amor, sexo y aventura en las mujeres del QUIJOTE. Madrid: Vindicación feminista, 1997.

Fox, Adam. Oral and Literate Culture in England I500-1700. Oxford: Clarendon Press, 2000.

Frenk, Margit. Entre la voz y el silencio. Alcalá de Henares: Centro de estudios cervantinos, 1997.

Gilman, Sander. "Los inquisidores literarios de Cervantes." Actas del Tercer Congreso Internacional de Hispanistas. México: 1970. 3-25.

Márquez Villanueva, Francisco. Personajes y temas del QUIJOTE. Madrid: Taurus, I975.

Narbona Vizcaíno, Rafael. Pueblo, poder y sexo: Valencia medieval (I306-I420). Valencia: Diputació de Valencia, (1989) 1992.

Nieto, Ramón. "Cuatro parejas en el Quijote." Cuadernos Hispanoamericanos: Revista Mensual de Cultura Hispánica 276 (1973): 496-527.

Perry, Mary Elizabeth. Gender and Disorder in Early Modern Seville. Princeton: Princeton UP, 1990.

Poska, Allyson M. "Ellusive Virtue: Rethinking the Role of Female Chastity in Early Modern Spain." Journal of Early Modern History 8.I (2004) I25-46.

-. "An Ocean Apart: Reframing Gender in the Spanish Empire." Women of the Iberian Atlantic. Eds. Sarah E. Owens and Jane E. Mangan. Baton Rouge: Louisiana State UP, 20I2. 37-56.

- " "When Love Goes Wrong: Getting Out of Marriage in Seventeenth-Century Spain." Journal of Social History (1996): 871-82. 
Resina, Joan Ramon. "What Sort of Wedding? The Orders of Discourse in El burlador de Sevilla." Modern Language Quarterly 57.4 (1996): 545-78.

Rico, Francisco. "La salvación de Don Juan." Breve biblioteca de autores españoles. Barcelona: Seix Barral, 1990. 239-68.

Rodríguez, Marie-Christine, and Bartolomé Bennassar. "Signatures et niveau culturel des témoins dans les proces d'inquisition du ressort du tribunal de Tolede (I527-I8I7) et du ressort du tribunal de Cordoue (I595-I632)." Cahiers du monde hispanique et luso-brésilien (Caravelle) 3I (1978): 17-46.

Stern, Steve J. The Secret History of Gender: Women, Men, and Power in Late Colonial Mexico. Chapel Hill: The U of North Carolina P, 1995.

Testón Nuñez, Isabel. Amor sexo y matrimonio en Extremadura. Badajoz: Universitas Editorial, 1985.

Thompson, I. A. A. War and Government in Habsburg Spain I560-I620. London: The Athlone Press, 1976.

Welles, Marcia L. Persephone's Girdle: Narratives of Rape in Seventeenth-Century Spanish Literature. Nashville: Vanderbilt UP, 2000.

Zavala, Iris M. Breve historia feminista de la literatura española (en lengua castellana), II: La mujer en la literatura española; Modos de representación desde la Edad Media hasta el siglo XVII. Barcelona: Anthropos,I995. 